\title{
Heat Stable $\alpha$ - and Glucoamylase Performing Deep Enzymatic Hydrolysis of Starch to Fermentable Glucose
}

\author{
Rusudan Khvedelidze, \\ Lali Kutateladze, \\ Tinatin Sadunishvili, \\ Nino Zakariashvili, \\ Zurab Darbaidze, \\ Tina Aleksidze,
}

Agricultural University of Georgia,

S. Durmishidze Institute of Biochemistry and Biotechnology

Doi:10.19044/esj.2019.v15n21p34 ～URL:http://dx.doi.org/10.19044/esj.2019.v15n21p34

\begin{abstract}
The temperature optimum for thermophilic strains, selected $\alpha$-amylase producers has been studied in the cultural liquids obtained after their submerged cultivation in the temperature range $30-45^{\circ} \mathrm{C}$, at $5{ }^{\circ} \mathrm{C}$ intervals. The temperature optimum of the strains was established to be within the range 68$72{ }^{\circ} \mathrm{C}$, making possible to use them in bio- and enzymatic technologies to diminish the pollution of the reaction medium while conducting the fermentation process at pasteurization temperature $\left(65^{\circ} \mathrm{C}\right)$. Consequently, the selection of stable, operable at pasteurization and higher temperatures amylase preparation is of great importance. Proposed technology is cost-effective, ecologically safe and competitive and provides deep hydrolysis of starch to fermentable sugar at the elevated temperature $\left(68-72{ }^{\circ} \mathrm{C}\right)$ in one-step, by means of only one, stable amylase preparation. Exhaustive hydrolysis process of starch solutions of different concentrations $(15,30$, and $40 \%)$ with cultural liquid and technical preparation of Aspergillus niger p8-3 enzyme was studied. In case of low concentrations exhaustive hydrolysis of starch lasts 40-60 minutes, in case of high concentrations hydrolysis takes longer time. 98,6\% Yield of glucose can be reached at incubation during 12 hours with enzyme cultural liquid and 8 hours incubation with technical preparation of the enzyme at gradual increase of temperature from $50^{\circ} \mathrm{C}$ to $82^{\circ} \mathrm{C}$ during the first 20 minutes and further decrease of temperature to $70^{\circ} \mathrm{C}$. Temperature setting for high yield of glucose and high hydrolysis (pasteurizing), optimal for activity of these strains is the prerequisite to be able to carry out hydrolysis of starch
\end{abstract}


to glucose in one step, and, consequently, using one strain, what will be economically justified.

Keywords: Amylase, Glucose, Hydrolysis, Stability, Extremophiles, Starch

\section{Introduction}

Production of enzyme preparations is one of the leading branches in modern biotechnology and represents a continuously growing area of the industry (Talebnia F, Karakashev D, Angelidaki I, 2010). Enzymatic biotechnologies should be considered as low power-consuming, waste less, and ecologically harmless ones with low risk level processes. Enzymes from fungal and bacterial sources have dominated applications in industrial sectors, as they are more stable than when prepared with plant and animal one, microbes are easy to manipulate to obtain enzymes of desired characteristics (Haki, G.D. et al., 2003). Representatives of this taxonomic group are wellknown producer's variety of extracellular and intracellular enzymes, antibiotics, hormones, vitamins, etc. (Satyanarayana, T. et al., 2005). About $40 \%$ of enzymes produces all over the world are used for obtaining fermenting sugar - glucose (Yennamalli M, et al., 2013) from raw materials containing starch (wheat, corn, potato, etc) by means of amylase activity (Maheshwari R. et al., 2000; Aquino A.C., et al., 2003). Amylases are one of the main enzymes used in industry. These enzymes hydrolyze the starch molecules into polymers composed of glucose units. In addition to starch hydrolysis, amylases have a number of other industrial applications. The $\alpha$-amylases have been widely used in the bakery industry. The addition of $\alpha$-amylase to the dough enhances the rate of fermentation and reduces the viscosity of dough, resulting in improvements in the volume and texture of the product; application of amylases generates additional sugar in the dough, which improves the taste, crust color and toasting qualities of the bread. A-Amylases also have an antistaling effect in bread baking. Amylases are used for the clarification of beer or fruit juices, or for the pretreatment of animal feed to improve the digestibility of fiber (Moxley G, Zhu Z, 2008). These enzymes are used in detergents for laundry and automatic dishwashing to degrade the residues of starchy foods such as potatoes, gravies, custard, chocolate, etc. Two main enzymes involved in starch hydrolysis are $\alpha$-amylase and glucoamylase. AAmylase hydrolyses $\alpha-1,4-$ glycosidic bonds randomly in amylose, amylopectin and glycogen in an endofashion. $\alpha$-Amylases bypass $\alpha-1,6$ glycosidic bonds and do not cleave them. Glucoamylase is an exo-acting enzyme hydrolyzing both $1,4-\alpha$ - and 1,6- $\alpha$-glycosidic linkages in polysaccharides yielding glucose. The use of amylases in starch-based industries has been prevalent for many decades and a number of microbial sources exist for the efficient production of this enzyme, but only a few 
selected strains of fungi and bacteria meet the criteria for commercial production (Rabinovich C, 2006; Kathiresan K, 2005). The basic problems use of enzymes in the industry are high cost and low stability of the great majority of commercial enzymes far not always satisfying the requirements of industrial processes. Stability of enzyme preparation determines sterility and effectiveness of the whole process. Consequently, the selection of stable, operable at pasteurization and higher temperatures amylase preparation is of great importance. Availability of stable forms of these enzymes would not only expand the area of their application, but also reduce the price of products produced by the use of these enzymes. Durmishidze Institute of Biochemistry and Biotechnology owns a unique collection of mycelial fungi, isolated from different ecological zones of the Caucasus, including extreme habitats (Kvesitadze G., 1999).

Receiving of the high activity amylase enzyme preparations is possible by detection of the producers of the active and stable amylase from the strains existing in collection of microorganisms. During the last 10 years, selection of microorganisms has clearly demonstrated that the searching for stable forms of enzymes is appropriate mainly among those microorganisms that exist within the relatively critical conditions (Pandey A. et al., 2000). Heat stable amylases, active at $65^{\circ} \mathrm{C}$ and higher, undoubtedly, will find application in production of alcohol and glucose-fructose syrup, and in other technologies where stability of enzymes, in many respects, defines sterility and efficiency of the entire process.

\section{Results and Discussion}

The use of amylases in starch-based industries has been prevalent for many decades and a number of microbial sources exist for the efficient production of this enzyme (Reginado A, Toni O, Wagner C, 2007), but only a few selected strains of fungi and bacteria meet the criteria for commercial production (Pritchard P, 2002). The basic problems use of enzymes in the industry are high cost and low stability of the great majority of commercial enzymes far not always satisfying the requirements of industrial processes. Availability of stable forms of these enzymes would not only expand area of their application, but also reduce the price of products produced by the use of these enzymes. In modern starch-based industries process of obtaining fermentable sugar - glucose from raw materials containing starch by means of amylases is running in two steps involving two enzymes of different origin: bacterial $\alpha$-amylase and fungal glucoamylase, due to their different heat stability, as generally fungal amylases are less thermostable as compared to bacterial amylases (Sundarram A, et al., 2014). Selection of stable and operable at $70^{\circ} \mathrm{C}$ and higher temperatures enzyme preparation with both $\alpha$ and glucoamylase activities will allow conducting this process in one- step. At 
Durmishidze Institute of Biochemistry and Biotechnology is created culture collection accounting more than 3000 individual strains of all taxonomic groups of microorganisms isolated from different ecological niches of South Caucasus As a result of screening our collection, 39 strains producing amylases were revealed (Picture 1).

Picture 1. Microscopic fungi of Different genera producers of amylases

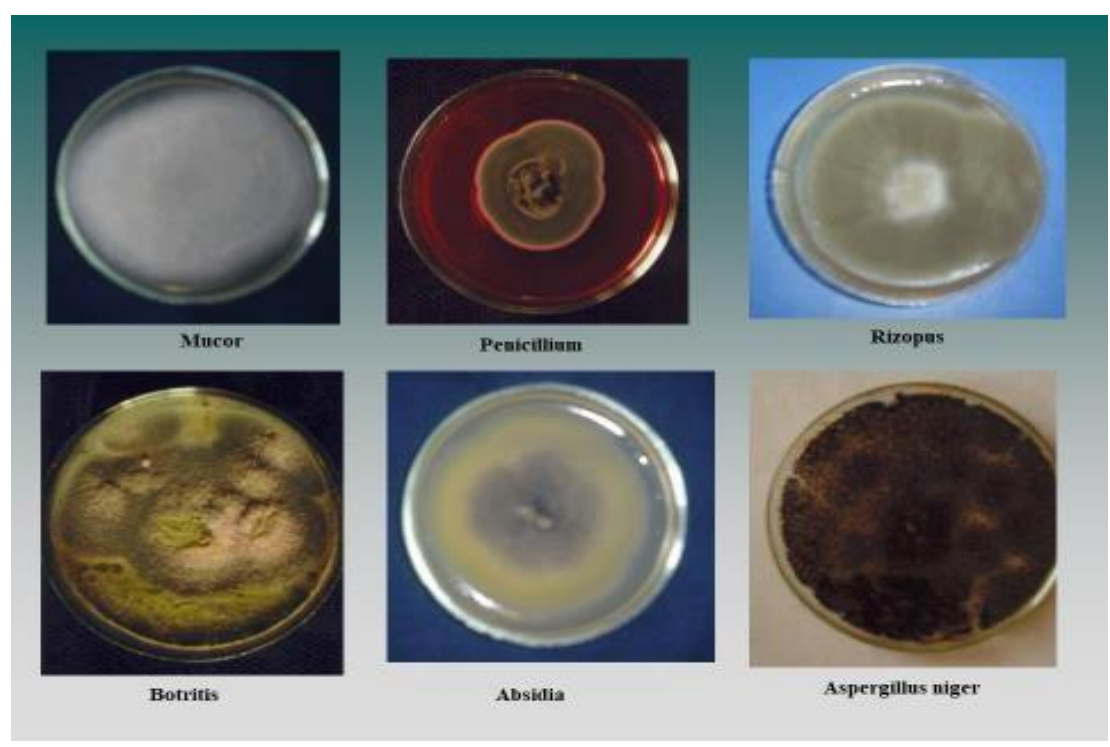

The Figure 1 shows frequency of strains producing amylase enzymes by the genera, which were isolated from different ecological niches of the Caucasus. As you can see, most of them belong to the genus Aspergillus. For father studies strains producing both $\alpha$ and glucoamylase were chosen (Fig. 1).

Fig.1 Microscopic fungi strains - producers of amylolytic enzymes

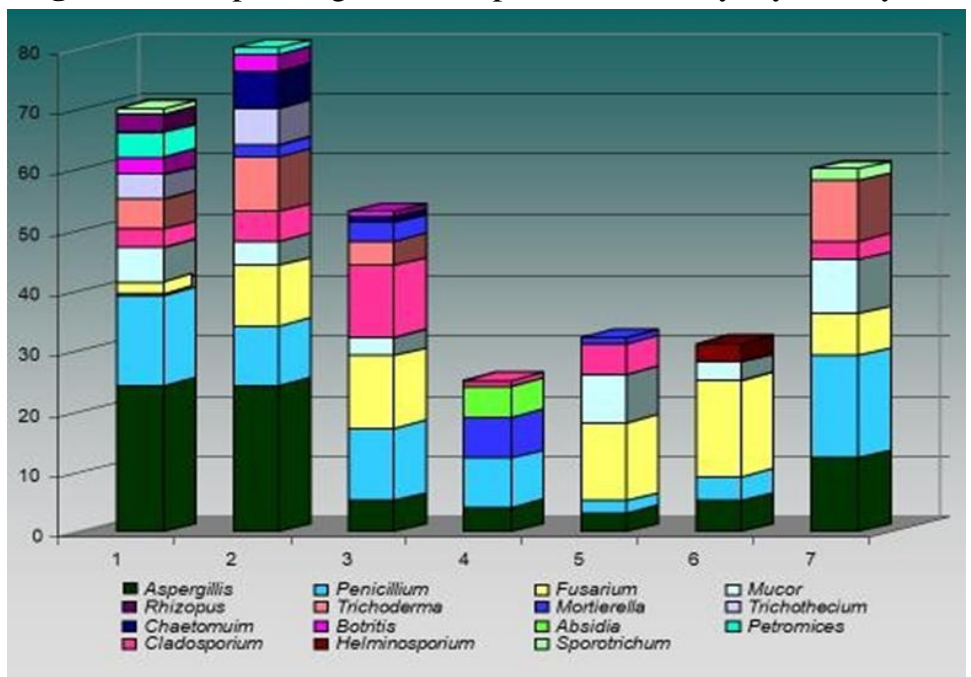


Sugar yield from starch is largely dependent on the type of amylases and their activities. This feature will largely determine enzyme loading and duration of hydrolysis, which in turn defines overall process economics. Stability of enzyme preparation determines sterility and effectiveness of the whole process. Producers with both $\alpha$ - and glucoamylase activities are given in Table 1.

Table 1. Extracellular activities of amylases from the selected strains

\begin{tabular}{|l|l|c|c|}
\hline$\#$ & \multicolumn{1}{|c|}{ Producer } & $\begin{array}{c}\boldsymbol{\alpha} \text {-Amylase } \\
\text { activity } \mathbf{~ / m l}\end{array}$ & $\begin{array}{c}\text { Glucoamylase } \\
\text { activity } \mathbf{~} / \mathbf{m l}\end{array}$ \\
\hline 1. & Aspergillus niger P8-3 & 0.67 & 40.0 \\
\hline 2. & Aspergillus niger B6 & 0.60 & 25.1 \\
\hline 3. & Aspergillus awamori S16 & 0.45 & 14.0 \\
\hline 4. & Aspergillus niger 6-12 & 0.45 & 29.0 \\
\hline 5. & Aspergillus oryzae BS 27 & 0.55 & 15.0 \\
\hline 6. & Mucor sp T 37 & 0.42 & 18.5 \\
\hline 7. & Rhizopus sp S 75 & 0.55 & 35.0 \\
\hline 8. & Penicillium sp. S 80 & 0.8 & 38.0 \\
\hline 9. & Penicillium sp.T 52 & 0.52 & 31.0 \\
\hline
\end{tabular}

Consequently, the selection of stable, operable at pasteurization temperature amylase preparation is of great importance (Pabulo Henrique Rampelotto 2010). Availability of stable forms of these enzymes would not only expand the area of their application, but also reduce the price of production.

Optimal temperatures of action of amylases from three producers were established to be within the range $67-80^{\circ} \mathrm{C}$. A. niger P8-3 showed higher $\alpha-$ amylase activity at $67^{\circ} \mathrm{C}$, and glucoamylase activity at $72^{\circ} \mathrm{C}$, A.oryzae B 27 showed higher $\alpha$-amylase activity at $40^{\circ} \mathrm{C}$, glucoamylase activity Aspergillus awamori T 23 at $52^{\circ} \mathrm{C}$, Aspergillus niger P8-3 showed higher activities at 67 ${ }^{\circ} \mathrm{C}$ and $72{ }^{\circ} \mathrm{C}$, for $\alpha$-amylase and glucoamylase activities respectively (Fig.2; Fig.3).

Fig.2 A-amylase activities of Aspergillus strains within the limit of $30-85{ }^{\circ} \mathrm{C}$

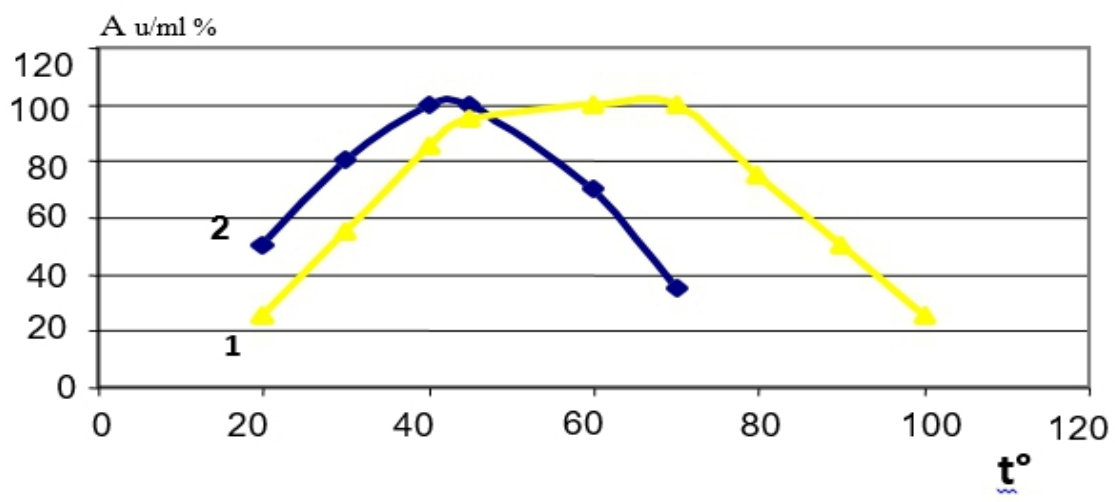

Aspergillus niger P8-3; 2. Aspergillus oryzae B 27 
Fig.3 Glucoamylase activities of Aspergillus strains within the limit of $30-85^{\circ} \mathrm{C}$

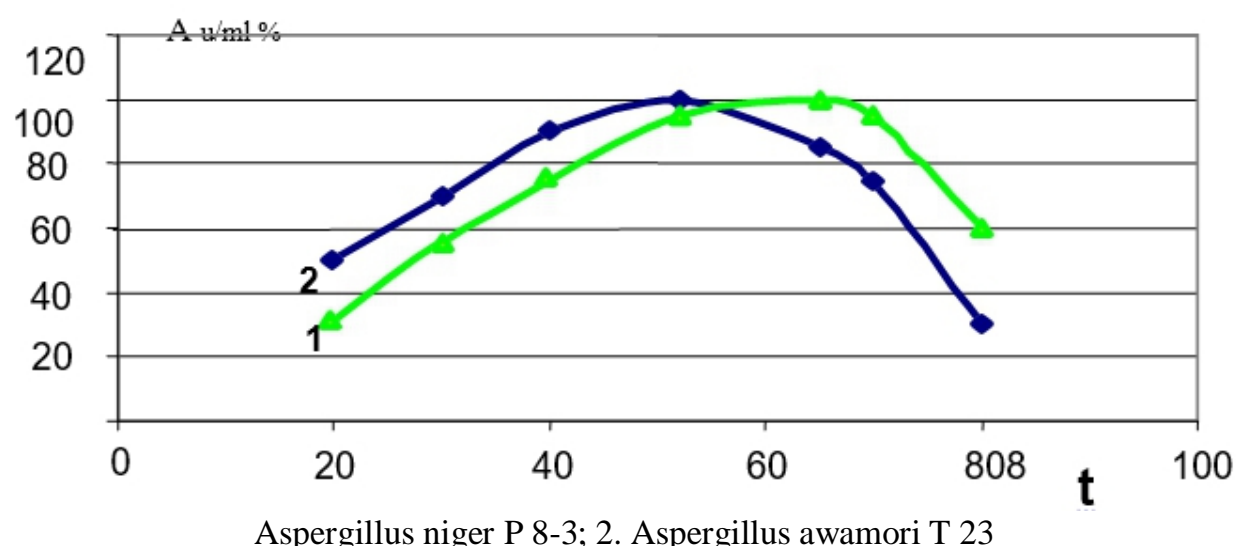

Enzyme technical preparations of most active and stable amylase producers were obtained using precipitation with ethyl alcohol, acetone, isopropanol, in different ratios. As conducted studies showed, precipitation by ethyl alcohol (1/3.0) was found the most efficient; the yields according to amylolytic activities make up 75-80\% (Table 2).

Table 2. Precipitation of $\alpha$-amylase from Cultural Solution via Addition of Organic Solvents

\begin{tabular}{|c|c|c|c|c|}
\hline Solvents & $\begin{array}{c}\alpha \text {-Amylase } \\
\text { activity } \\
\mathrm{U} / \mathrm{ml}\end{array}$ & $\begin{array}{c}\text { Protein } \\
\mathrm{mg} / \mathrm{ml}\end{array}$ & $\begin{array}{c}\text { Specific } \\
\text { activity U/ml }\end{array}$ & $\begin{array}{c}\text { Activity } \\
(\%)\end{array}$ \\
\hline Ethyl alcohol, 1:2 & 35.0 & 0.73 & 0,47 & 55 \\
\hline Ethyl alcohol 1:3 & 50.0 & 0.82 & 60.9 & 75 \\
\hline Ethyl alcohol 1:4 & 47.0 & 0.85 & 55.2 & 65 \\
\hline Acetone, 1:2 & 30.2 & 0.78 & 38.8 & 45 \\
\hline Acetone, $1: 3$ & 45.3 & 0.85 & 53.2 & 52 \\
\hline Acetone, $1: 4$ & 48.1 & 0.90 & 53.4 & 52 \\
\hline
\end{tabular}

Exhaustive hydrolysis process of starch solutions of different concentrations $(5,10,30$ and $40 \%)$ with technical preparation of Aspergillus niger $\mathrm{p} 8-3$.

The process of starch hydrolysis consists of several steps. Native starch occurs in the form of discrete and crystalline microscopic granules that are held together by an extended micellar network of associated molecules. As a result of this structural arrangement, starch is insoluble in cold water. Because of it at the first stage, we heat starch solution in order to gelatinize starch. During gelatinization, the monogram-sized starch granules are dissolved and form viscous suspension. 
Exhaustive hydrolysis process of starch solutions of different concentrations $(5,10,30$ and $40 \%)$ with technical preparation of Aspergillus niger p8-3 with $\alpha$-amylase activity $8,6 \mathrm{u} / \mathrm{g}$ and glucoamylase activity $225 \mathrm{u} / \mathrm{g}$. According to the rule of $1 \mathrm{~g}$. starch needing $60 \mathrm{u}$ of glucoamylase and $30 \mathrm{u}$ of $\alpha$-amylase activity, enzyme was studied at $68^{\circ} \mathrm{C}$. In case of starch low concentrations exhaustive hydrolysis of starch lasts 20-90 minutes, in case of high concentrations hydrolysis takes longer time. 96-98\% Yield of glucose can be reached at incubation $30 \%$ and $40 \%$ of starch during 8 hours with the technical preparation of the studied fungal enzyme (Table 3 ).

Table 3. Starch hydrolysis by amylase technical preparation of niger p 8-3

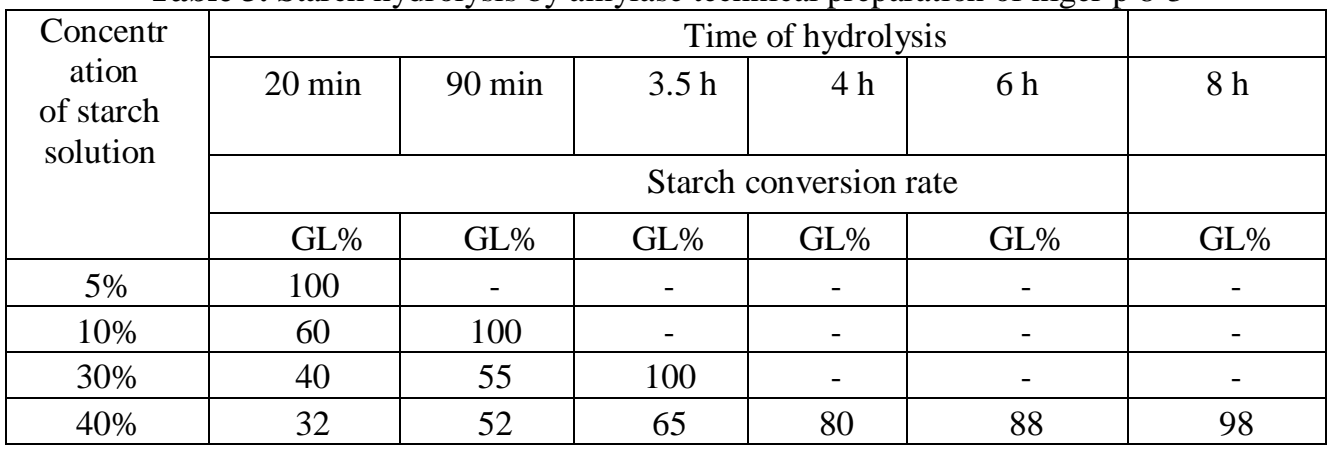

\section{Material and Methods}

\section{Cultivation conditions}

Screening of strains active amylase producers was hold in submerged cultures. Conidial suspension of 10-12 days cultures served as inocula. Cultivation was conducted in $750 \mathrm{ml}$ Erlenmeyer flasks, on temperaturecontrolled shaker (160-220 rev/min) at $30^{\circ} \mathrm{C}$, for 72 hours. In order to obtain amylases, in deep cultivation was carried out in a liquid medium supplemented with \%: starch - 6.0; NaNO3 - 0.91; KH2PO4-0.1; MgSO4×7H2O - 0.05, $\mathrm{KCl}-0.05$, FeSO $4-0.0002$, malt extract- $1.5 \mathrm{ml}$. per $50 \mathrm{ml}$ (Brahmachari G. etc. 2017.). After cultivation, the culture solution was centrifuged at $4000 \mathrm{rpm}$. In the cultural liquids obtained after the submerged cultivation, the amylase activity was studied.

Determination of $\boldsymbol{\alpha}$-amylase activity was based on the decreased staining value of blue starch-iodine complex, according to Liu and $\mathrm{Xu}(9)$ with a few modifications. First, $10 \mathrm{ml}$ of $1 \%$ (w/v) soluble starch (pH 4.7 sodium acetate buffer) was pre-incubated for $5 \mathrm{~min}$, and then $1 \mathrm{ml}$ of appropriately diluted enzyme sample was added. After 10 min of reaction, $0.2 \mathrm{ml}$ of the reaction mixture was removed and put into a tube containing $10 \mathrm{ml}$ of $0.1 \mathrm{M}$ $\mathrm{HCl}$ with iodine solution. The absorbance of the final solution was measured at $650 \mathrm{~nm}$.

Glucoamylase activity was determined by peroxidase/glucoseoxidase enzymatic method described by Bergmeyer and Bernt (Acourene S, 
2012) with modification. $10 \mathrm{ml}$ of $1 \%$ starch solution in $\mathrm{pH} 4.7$ sodium acetate buffer was incubated with $1 \mathrm{ml}$ diluted crude enzyme. After $10 \mathrm{~min}$ incubation samples were cooled in an ice water bath. From this reaction mixture, an aliquot of $1 \mathrm{~mL}$ was taken and $3 \mathrm{ml}$ of the glucose oxidase reagent was added, after $30 \mathrm{~min}$ the absorbance was measured at $420 \mathrm{~nm}$.

To obtain enzymatic preparations, filtrate of culture liquid was centrifuged at $4000 \mathrm{rpm}$ and cooled to $+4^{\circ} \mathrm{C}$. Ethyl alcohol (1/4) was added to cold enzyme solution under the conditions of gradual stirring. After 20-30 min formed pellet was removed by centrifugation (4000 rpm for 10 minutes) and lyophilized (Das S. et al., 2011).

To determine temperature optimums of activity for amylase enzymatic preparations, enzymatic activity was measured between $20^{\circ} \mathrm{C}$ $80^{\circ} \mathrm{C}$, by $5^{\circ} \mathrm{C}$ temperature intervals. A- and glucoamylase activities were determined by the above mentioned methods and expressed as percentage of maximum activity.

Temperature dependence of $\alpha$-amylase activity was measured over a temperature range of $40-90{ }^{\circ} \mathrm{C}$ at $\mathrm{pH}$ 5.0. Thermal inactivation of the enzyme was done by incubating the enzyme at $60{ }^{\circ} \mathrm{C}$ and $55^{\circ} \mathrm{C}(\mathrm{pH} 7.0$, the $\mathrm{pH}$ of purified enzyme solution). Samples were removed at different time intervals (10-60 min) and immediately cooled on ice. Residual activity was measured using the standard assay method. (Fernandes Pedro, 2010).

Determination of glucose. The amount of glucose was determined by glucosooxidase-peroxidase method; $3 \mathrm{ml}$ of glucosooxidase-peroxidase reagent was added to $0.2 \mathrm{ml}$ of analyzing solution. After delaying for 30 minutes, the intensity of formed color was measured on spectrophotometer at $420 \mathrm{~nm}$ of wavelength. The amount of glucose was estimated by preliminarily diagrammed calibration curve.

\section{Conclusion}

Temperature setting for high yield of glucose and deep hydrolysis, optimal for the activity of these amylase preparations is the prerequisite enabling to carry out one-step hydrolysis of starch to glucose, which is an essential substrate for numerous fermentation processes in a range of food and beverage industries, and consequently, to use one enzyme preparation, that will be economically justified.

The proposed technology could have wide application in different fields of industries based on starch hydrolysis (Haki G. 2003, Adejumo A. 2009). Advantages: Ecologically friendly as compared to chemical hydrolysis (Hakiand G, Rakshit S, 2003). Cost-effective, the technology is based on application of one technical enzyme preparation obtained from aspergillus as compared to alternative technology based on application of two enzyme preparations from different producers bacteria and fungi (making the process 
much more expensive (Uthumporn U. et al., 2010; Dutt K. et al., 2007). High temperature $\left(68^{\circ} \mathrm{C}\right.$ and above) setting of starch hydrolysis defining sterility and efficiency of the entire process. The technology allows hydrolysing high concentrated starch (40\%). The proposed technology could have wide application in different fields of industry based on starch hydrolysis. (Saranraj P., 2013). Application of one enzyme preparation for starch deep hydrolysis with high yield of glucose will make the process cost-effective what will be economically justified (Gupta A. et al., 2008; Iu Y, Xu Y., 2008).

At Durmishidze Institute of Biochemistry and Biotechnology is created culture collection accounting more than 3000 individual strains of all taxonomic groups of microorganisms isolated from different ecological niches of South Caucasus. As a result of screening among the collection three promising microscopic fungi strains of genus Aspergillus producers of amylases with optimal temperature of action in range $68-72{ }^{\circ} \mathrm{C}$ with high $\alpha$ and glucoamylase activities were revealed. Enzyme technical preparation precipitation by ethyl alcohol (1/3.0) was found the most efficient; the yields according to amylolytic activities make up 75-80\% (Table 2). High concentration (40\%) starch conversion rate with cultural liquid and technical preparations of amylases is 96-98\% (Table 3). Based on this data, we have elaborated original technology of starch enzymatic hydrolysis, which enable to obtain high yield of glucose $(98 \%)$ in a short time ( 8 hours), at high temperature $\left(68-72^{\circ} \mathrm{C}\right)$, using just only one enzyme preparation.

\section{References:}

1. Acourene S. Ammouche A. Optimization of ethanol, citric acid, and $\alpha$ - amylase production from date wastes by strains of Saccharomyces cerevisiae, Aspergillus niger, and Candida guilliermondii, J India Microbiol Biotechnol. 39 (2012) 759-766.

2. Adejumo A. Agboola F. Lauokun S. Hydrolysis of maize starch using amylolytic enzymes extracted from sorghum malt, Int. J. Biol. Chem. Sci. 3(5) (2009) 1030-1041.

3. Aquino A. Jorje J. Terenzi H. Polizeli M. Studies on a thermostable $\alpha-$ amylase from the thermophilic fungus Scytalidium thermophilum. Appl Microbiol Biotechnol. 61, v. 4 (2003) 323-328.

4. Brahmachari G. Demain A. Adrio J. Biotechnology of Microbial Enzymes, Chapter 11 (2017) 267-298.

5. Das S. Singh S. Sharma V. Soni M. Biotechnological applications of industrially important amylase enzyme, International Journal of Pharma \& Bio Sciences. 2 (1) (2011) 5.

6. Dutt K. Agarwal L. Nayyar P. A highly thermostable and alkaline amylase from a Bacillus sp. PN5, Bioresour Technol. 98 (2007) 260265. 
7. Fernandes P. Enzymes in Food Processing: A Condensed Overview on Strategies for Better Biocatalysts v.112 (2010) 1-19.

8. Gupta A. Gupta V. Modi D. Yadava L. Production and characterization of $\alpha$-amylase from Aspergillus niger, Biotechnology. 7 (2008) 551-556.

9. Haki G. Rakshit S. Developments in industrially important thermostable enzymes: a review Bioresource Technology v.89 (1) (2003) 56-67

10. Haki G. Rakshit S. Development of industrially important thermostable enzymes a review, Bioresource Technology. v. 89 (2003) 17-34.

11. Hakiand G. Rakshit S. A review. Biores. Technol. (2003) 89, 17-34

12. Iu Y. Xu Y. A novel raw starch digesting $\alpha$-amylase from a newly isolated Bacillus sp. YX-1: purification and characterization, Bioresour. Technol. 99 (2008) 431-439.

13. Kathiresan K. Manivannan S. Amylase production by Penicillium fellutanum isolated from mangrove rhizosphere soil, Centre of advanced study in Marine Biology, Annamalai University, Parangipettai, 608502, Tamilnadu, India. 2005, pp. 28.

14. Kvesitadze G. Kvesitadze E. Biotechnology, Tbilisi, "Etrati”, 1999 (in Georgian).

15. Maheshwari R. Bharadwaj G. Bhat M. Thermophilic Fungi: Their Physiology and Enzymes, Microbiology and Molecular Biology Review v. 64 N 3 (2000) 461-488.

16. Moxley G, Zhu Z, Percival Zhand; Agric. Food Chem (2008) 56, 78857890

17. Pabulo Henrique Rampelotto; Sustainability, (2010) 2, 1602-1623.

18. Pandey A. Nigam P. Soccol C. Soccol V. Singh D. Mohan R. Advances in microbial amylases, Biotechnol. Appl. Biochem. V.31 (2000) 135-152.

19. Pritchard P. Studies on the bread improving mechanisms of fungal amylase, Journal of Biological Education. 26 (2002) 12-18.

20. Rabinovich C. Amylolytic enzymes and their application in alcohol industry. Moscow, 2006 (in Russian).

21. Reginado A, Toni O, Wagner C. Plant Physiology (2007). V.19, 1013

22. Saranraj P. Stella D. Fungal Amylase, International Journal of Microbiological Research. 4(2) (2013) 203-211.

23. Satyanarayana T. Raghukumar C. Shivaji S. Extremophilic Microbes: Diversity and perspectives, Current Science, vol. 89 N 1 (2005) 45-62.

24. Sundarram A. Pandurangappa T. Murthy K. $\alpha$-Amylase Production and application, Journal of Applied \& Environmental Microbiology. v. 2 - 4 (2014) 166-175. 
25. Talebnia F, Karakashev D, Angelidaki I. Bioresource Technology, (2010) V.101(13). 4744-4744.

26. Uthumporn U. Zaidul S. Karim A. Hydrolysis of granular starch at sub-gelatinization temperature using a mixture of amylolytic enzymes, Food and Bioproducts Processing, v. 88 (2010) 47-54.

27. Yennamalli M, Rader I, Kenny J, Wolt D, Sen Z. Biotechnologies for Biofuels (2013). 6:136.11. 